\title{
Insidens Malnutrisi Rawat Inap pada Anak Balita di Rumah Sakit Umum Pusat Sanglah Denpasar
}

\author{
I Gusti Lanang Sidiartha \\ Divisi Nutrisi dan Metabolik. Bag/SMF IKA FK-UNUD/RSUP Sanglah Denpasar
}

\begin{abstract}
Latar belakang. Malnutrisi merupakan salah satu masalah serius di bidang kesehatan anak balita baik di negara maju maupun negara sedang berkembang karena angka kesakitan dan kematian masih tinggi.

Tujuan. Mengetahui insidens malnutrisi rawat inap pada anak balita dan menganalisis hubungannya dengan berbagai faktor seperti jenis kelamin, umur, jenis penyakit, tipe malnutrisi dan lama rawat.

Metode. Penelitian kohort retrospektif dikerjakan terhadap 103 anak balita rawat inap di Bangsal Anak RSUP Sanglah bulan Nopember 2006 sampai Januari 2007. Malnutrisi rawat inap ditentukan dengan menghitung selisih nilai $Z$-score $\mathrm{BB} / \mathrm{TB}$ saat masuk rumah sakit dan saat pulang dengan cut off point 0,5 SD. Hubungan dengan jenis kelamin, umur, jenis penyakit, tipe malnutrisi dan lama rawat diuji dengan uji kai-kuadrat dengan tingkat kemaknaan $\mathrm{p}<0,05$.

Hasil. Diantara 103 anak balita 66\% laki-laki dan 34\% perempuan, 44,6\% berumur <12 bulan, 24,3\% dengan diagnosis diare, dan lama rawat antara 2-29 hari. Insidens malnutrisi rawat inap dijumpai pada 31 dari 103 anak (30,1\%). Insidens malnutrisi rawat inap pada anak dengan lama rawat 8-29 hari 58,8\% dan lama rawat 2-7 hari 15,9\%, secara statistik bermakna (p=0,000; RR 3,69; IK95\% 2,00; 6,79). Hubungan malnutrisi rawat inap dengan jenis kelamin, umur, jenis penyakit, dan tipe malnutrisi tidak bermakna (masing-masing nilai $\mathrm{p}>0,05$ ).

Kesimpulan. Insidens malnutrisi rawat inap di RSUP Sanglah 30,1\%, risiko malnutrisi rawat inap meningkat 3,69 kali apabila anak dirawat lebih dari seminggu (Sari Pediatri 2008;9(6):381-85).
\end{abstract}

Kata kunci: malnutrisi rawat inap, lama rawat, balita

\footnotetext{
Alamat korespondensi

Dr. I Gst Lanang Sidiartha, SpA. Divisi Nutrisi \& Metabolik. Bag/SMF IKA FK-UNUD RSUP Sanglah Jl. P Nias, Denpasar Telp/Fax. (0361)244038, Email: lanangsidiartha@yahoo.com
}

Makalah telah disajikan dalam Seminar Peranan Tunjangan Nutrisi dalam Mengoptimalkan Perawatan Pasien di Rumah Sakit, HUT BKFK ke-45 dan Temu Alumni, Denpasar, 2 Maret 2007.

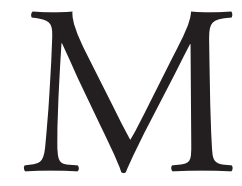

alnutrisi menurut World Health Organization (WHO) adalah ketidak seimbangan antara asupan dan kebu tuhan nutrisi untuk menjamin pertumbuhan yang optimal. ${ }^{1}$ Hingga saat ini malnutrisi merupakan salah satu masalah serius di bidang kesehatan anak, baik di negara maju maupun di negara sedang berkembang. Di Amerika 22-35\% anak berumur 2-6 
tahun underweight dan $11 \%$ stunting. ${ }^{2}$ Data WHO (2000) memperlihatkan 181,9 juta (32\%) anak di negara sedang berkembang mengalami malnutrisi. ${ }^{3}$ Peneliti lain menyebutkan $80 \%$ anak malnutrisi berada di Asia, 15\% di Afrika dan 5\% di Amerika Latin. ${ }^{4}$ Di Indonesia, pada Repelita VI pemerintah bersama masyarakat berupaya menurunkan prevalensi malnutrisi dari $40 \%$ menjadi 30\%. ${ }^{5}$ Di RSUP Sanglah Denpasar, selama periode April 1998 - Juni 1999 ditemukan 412 kasus malnutrisi dari 3790 anak yang dirawat di Bangsal Anak. ${ }^{6}$

Malnutrisi sangat erat kaitannya dengan berbagai penyakit seperti diare dan infeksi saluran pernapasan. Di negara sedang berkembang, 25\% kasus malnutrisi mengalami diare dan sebaliknya 60\% kematian diare dilatarbelakangi oleh malnutrisi. ${ }^{7}$ Pasien diare disertai malnutrisi akan menjalani rawat inap lebih lama apabila malnutrisi tidak ditangani dengan baik, dan pemberian suplementasi nutrisi selama diare akan mempercepat kesembuhan. ${ }^{8}$

Prevalensi malnutrisi pada anak berbasis komunitas sudah banyak diteliti, namun insidens malnutrisi pada anak rawat inap belum ada data. Penelitian ini bertujuan mengetahui insidens malnutrisi pada anak balita rawat inap dan menganalisis hubungannya dengan berbagai faktor seperti jenis kelamin, umur anak, jenis penyakit, tipe malnutrisi dan lama rawat.

\section{Metode}

Rancangan penelitian adalah kohort retrospektif. Data diperoleh dari catatan medis Divisi Nutrisi dan Metabolik, Bagian Ilmu Kesehatan Anak FK UNUD/ RSUP Sanglah Denpasar periode bulan Nopember 2006 sampai Januari 2007. Subjek penelitian adalah anak berusia antara 1 sampai 59 bulan yang menjalani rawat inap di Bangsal Anak RSUP Sanglah. Pada anak rawat inap berulang selama periode penelitian dipakai, data antropometri yang dipergunakan adalah saat rawat inap pertama. Anak tidak diikutsertakan dalam penelitian apabila catatan medis tidak lengkap dan/ atau saat pulang berstatus pulang paksa atau meninggal.

Pengukuran antropometri sesuai dengan prosedur tetap Bagian Ilmu Kesehatan Anak RSUP Sanglah Denpasar. Status nutrisi menggunakan indikator berat badan per umur (underweight bila $Z$-score $<-2 S D$ ), tinggi badan per umur (stunting bila $Z$-score $<-2 \mathrm{SD}$ ) dan berat badan per tinggi badan (wasting bila $Z$-score $<-2 S D)$. Penghitungan ketiga indikator menggunakan software WHO ANTHRO berdasarkan standar baku antropometri WHO tahun 2006. ${ }^{910}$ Malnutrisi Rawat Inap (MRI) ditentukan dengan menghitung selisih nilai $Z$-score $\mathrm{BB} / \mathrm{TB}$ pada saat masuk rumah sakit (MRS) dan saat pulang dengan kriteria penurunan nilai $Z$-score 0,5 SD. ${ }^{11}$ Definisi MRI apabila terjadi penurunan nilai $Z$-score $\mathrm{BB} / \mathrm{TB} \geq 0,5 \mathrm{SD}$ antara $\mathrm{BB} /$ TB saat masuk rumah sakit dan saat pulang.

Data jenis kelamin, tanggal lahir, tanggal MRS dan tanggal pulang serta diagnosis penyakit diperoleh dari catatan medis. Lama rawat dihitung dalam hari, berdasarkan selisih antara tanggal MRS dan tanggal pulang. Penghitungan indikator antropometri menggunakan dua nilai umur yaitu umur saat masuk rumah sakit dan saat pulang.

Besar sampel dihitung berdasarkan perkiraan insidens malnutrisi rawat inap dari laporan $40 \%,{ }^{8}$ dengan penetapan presisi sebesar $15 \%$, tingkat kemaknaan $\alpha<0,05$ dan power penelitian 80\% maka besar sampel minimal yang dibutuhkan 102 subjek.

Data yang terkumpul diproses dengan sistem komputer. Pada bagian deskriptif dilakukan penghitungan prevalensi underweight, stunting dan wasting pada saat masuk rumah sakit dan saat pulang, insidens MRI, dan variabel lain seperti jenis kelamin, umur, diagnosis penyakit dan lama rawat. Pada bagian analitik hubungan antara MRI dengan variabel jenis kelamin, umur anak, diagnosis penyakit, tipe malnutrisi saat masuk rumah sakit dan lama rawat diuji dengan uji kai kuadrat dan uji Fisher. Peneliti juga menghitung risiko relatif (RR) dan interval kepercayaan 95\% (IK95\%) variabel jenis kelamin, umur, diagnosis penyakit, tipe malnutrisi saat masuk rumah sakit dan lama rawat terhadap insidens MRI. Nilai signifikansi secara statistik seluruh uji apabila nilai $\mathrm{p}<0,05$. Penelitian sudah mendapat persetujuan dari komite etik FK UNUD/RSUP Sanglah Denpasar.

\section{Hasil}

Jumlah anak yang tercatat pada catatan medis Divisi Nutrisi dan Metabolik selama bulan Nopember 2006 sampai Januari 2007 adalah 180 orang anak. Namun, 77 anak tidak diikutkan dalam penelitian, diantaranya oleh karena usia sudah 5 tahun atau lebih (31 anak); meninggal selama dalam perawatan ( 3 anak); pulang paksa (2 anak) dan data tidak lengkap (41 anak). Sisanya 103 anak merupakan subjek penelitian. Dari 103 anak 
terdiri dari 66\% laki-laki dan 34\% perempuan. Distribusi anak menurut kelompok umur terbanyak umur $<12$ bulan $(44,6 \%)$. Diagnosis penyakit terbanyak adalah diare $(24,3 \%)$, pneumonia $(19,4 \%)$ dan sisanya adalah tonsilofaringitis, kejang demam, epilepsi, demam berdarah dengue, sepsis, hepatitis, ensefalitis, penyakit jantung bawaan, kolestasis, morbili, anemia, infeksi saluran kemih, dan malaria. Malnutrisi rawat inap ditemukan pada 31 dari 103 anak (30,1\%), karakteristik subjek tertera pada Tabel 1 .

Insidens MRI memiliki hubungan yang bermakna secara statistik dengan lama rawat $(\mathrm{p}=0,000)$. Lama rawat 8-29 hari memiliki risiko relatif terjadi malnutrisi 3,69 kali dibandingkan lama rawat 2-7 hari. Variabel jenis kelamin, umur, diagnosis penyakit dan tipe malnutrisi saat masuk rumah sakit tidak memiliki hubungan secara statistik dengan insidens MRI, nilai p masing-masing $>0,05$ (Tabel 2).

\section{Diskusi}

Belum ada kepastian penentuan kriteria untuk malnutrisi rawat inap, maka peneliti mempergunakan batasan yang digunakan oleh Kac dkk, ${ }^{11}$ yaitu penurunan nilai $Z$-score sebesar $0,5 \mathrm{SD}$ atau lebih antara nilai $Z$-score saat masuk dan saat keluar dari
Tabel 1. Karakteristik subjek penelitian

\begin{tabular}{lcc}
\hline Karakteristik & $\mathrm{n}$ & $\%$ \\
& (Total = 103) & \\
\hline Jenis kelamin & & \\
- Laki & 68 & 66,0 \\
- Perempuan & 35 & 34,0 \\
Umur (bulan) & & \\
- 1-11 & 46 & 44,6 \\
- 12-35 & 36 & 35,0 \\
- 36-59 & 21 & 20,4 \\
Diagnosis & & \\
- Pneumonia & 20 & 19,4 \\
- Diare & 25 & 24,3 \\
- Lain-lain & 58 & 56,3 \\
Malnutrisi saat masuk rumah sakit & & \\
- Underweight & 15 & 14,6 \\
- Stunting & 26 & 25,2 \\
- Wasting & 18 & 17,5 \\
Malnutrisi saat pulang rumah sakit & & \\
- Underweight & 24 & 23,3 \\
- Stunting & 26 & 25,2 \\
- Wasting & 25 & 24,3 \\
Lama rawat (hari) & & \\
- 8-29 & 34 & 33,0 \\
- 2-7 & 69 & \\
- MRI & & \\
\hline
\end{tabular}

${ }^{*} \mathrm{MRI}=$ malnutrisi rawat inap

Tabel 2. Insidens malnutrisi rawat inap dan hubungannya dengan beberapa variabel

\begin{tabular}{|c|c|c|c|c|}
\hline Variabel & $\begin{array}{l}\text { MRI } \\
(n, \%)\end{array}$ & $\mathrm{P}$ & $\mathrm{RR}$ & IK (95\%) \\
\hline \multicolumn{5}{|l|}{ Jenis kelamin } \\
\hline • Laki & $20(29,4)$ & & & \\
\hline - Perempuan & $11(31,4)$ & $0,833^{\mathrm{a}}$ & 0,93 & $0,50-1,72$ \\
\hline \multicolumn{5}{|l|}{ Umur (bulan) } \\
\hline • 1-11 & $15(32,6)$ & & & \\
\hline - $12-35$ & $13(36,1)$ & & & \\
\hline - $36-59$ & $3(14,3)$ & $0,197^{a}$ & 2,52 & $0,81-7,85$ \\
\hline \multicolumn{5}{|l|}{ Diagnosis } \\
\hline - Pneumonia & $7(35,0)$ & & & \\
\hline - Diare & $10(40,0)$ & & & \\
\hline • Lain-lain & $14(24,1)$ & $0.305^{\mathrm{a}}$ & 1,65 & $0,85-3,21$ \\
\hline \multicolumn{5}{|c|}{ Malnutrisi saat masuk RS } \\
\hline - Underweight & $8(53,3)$ & $0,063^{b}$ & 2,04 & $1,13-3,67$ \\
\hline - Stunting & $10(38,5)$ & $0,282^{a}$ & 1,41 & $0,76-2,59$ \\
\hline - Wasting & $7(38,9)$ & $0,371^{\mathrm{a}}$ & 1,37 & $0,70-2,69$ \\
\hline \multicolumn{5}{|l|}{ Lama rawat (hari) } \\
\hline - 8-29 & $20(58,8)$ & & & \\
\hline - $2-7$ & $11(15,9)$ & $0,000^{a}$ & 3,69 & $2,00-6,79$ \\
\hline
\end{tabular}

${ }^{a}$ Uji Kai Kuadrat; ${ }^{\text {b } U j i ~ F i s h e r ~}$ 
rumah sakit. Peneliti Geila dkk, ${ }^{8}$ menggunakan istilah insidence of weight loss untuk menentukan dampak rawat inap terhadap status nutrisi anak balita, perhitungan dilakukan dengan memperhatikan setiap penurunan berat badan antara saat masuk dan saat pulang dari rumah sakit. Peneliti memperoleh insidens MRI 30,1\%, Kac G dkk melaporkan 15,5\% sedangkan Geila dkk ${ }^{8}$ memperoleh 51,6\%. Perbedaannya, peneliti sebelumnya menggunakan nilai $Z$-score indikator BB/ $\mathrm{U}$, karena tidak memiliki data tinggi badan anak pada saat pulang dari rumah sakit. ${ }^{11}$ Peneliti menggunakan nilai $Z$-score indikator $\mathrm{BB} / \mathrm{TB}$ dengan pertimbangan hasil pengukuran tinggi badan relatif sama antara tinggi badan saat masuk dan saat pulang sedangkan umur berubah antara umur saat masuk dan umur saat pulang dari rumah sakit. Perbedaan lain yang menyebabkan nilai tidak sesuai adalah Kac dkk, ${ }^{11}$ menggunakan umur anak $<10$ tahun sehingga anak yang berumur $>5$ tahun yang memiliki insidens malnutrisi lebih rendah akan menyebabkan insidens secara keseluruhan lebih rendah. Sedangkan Geila dkk hanya memperhitungkan penurunan berat badan tanpa cut off point sehingga insidens malnutrisi menjadi lebih tinggi.

Malnutrisi pada anak balita yang menjalani rawat inap, perlu mendapatkan perhatian yang serius dan dipertimbangkan untuk merawat setiap anak balita secara multidisiplin dengan memantapkan kerja sama dalam tim asuhan gizi rumah sakit. Anak yang menjalani rawat inap mengalami stres yang luar biasa. Di satu sisi akibat penyakitnya menyebabkan nafsu makan menurun sehingga asupan nutrisi berkurang, di sisi lain kebutuhan akan nutrisi meningkat untuk melawan berbagai kuman penyebab dalam tubuh. Lingkungan rumah sakit yang asing dan berbagai prosedur tindakan medis yang harus dijalani akan menambah beban penderitaan bagi si anak. Dampaknya akan menyebabkan malnutrisi, sehingga memperberat penyakitnya dan memperlambat masa penyembuhan.

Berbagai faktor risiko telah diketahui terkait dengan insidens MRI. Dari lima faktor risiko (jenis kelamin, umur, diagnosis penyakit, tipe malnutrisi saat masuk rumah sakit dan lama rawat), hanya lama rawat yang memiliki hubungan dengan insidens MRI baik pada uji bivariat maupun uji multivariat (data tidak dicantumkan). Anak yang dirawat inap lebih dari seminggu memiliki risiko mengalami MRI 3 kali lebih besar dibandingkan dengan anak yang dirawat kurang dari seminggu, sejalan dengan dua penelitian sebelumnya ${ }^{8,11}$ Kondisi ini dapat dijelaskan, yaitu pada anak yang dirawat lebih lama akan semakin tinggi terpapar oleh infeksi nosokomial dan situasi yang jauh dari lingkungan keluarga akan menambah penurunan nafsu makan si anak.

Diagnosis penyakit saat MRS tidak memiliki hubungan dengan insidens MRI. Berbeda dengan penelitian sebelumnya yang menyatakan diagnosis pneumonia memiliki insidens malnutrisi paling tinggi yang dicurigai disebabkan karena puasa yang lama, gagal mengidentifikasi kebutuhan nutrisi yang meningkat akibat infeksi, dan yang terpenting terapi nutrisi tidak secara rutin dikerjakan sebagai fasilitas pelayanan kesehatan. ${ }^{8}$ Perlu dicermati adalah insidens MRI terbanyak terjadi pada pasien diare. Keadaan ini agak kontradiktif, yang semestinya pada pasien diare saat pulang memiliki berat badan yang meningkat oleh karena telah keadaan dehidrasi telah teratasi. Ini cermin bahwa memang terjadi malnutrisi selama dalam perawatan karena menurunnya fat mass dan/atau lean body mass, bukan semata-mata karena kehilangan cairan.

Status nutrisi saat masuk tidak memiliki hubungan bermakna dengan insidens MRI sehingga status nutrisi awal tidak berpengaruh terhadap timbulnya MRI. Saat pulang dari rumah sakit prevalensi underweight meningkat $8,7 \%$ dari $14,6 \%$ saat masuk menjadi $23,3 \%$ saat pulang dan prevalensi wasting meningkat $6,8 \%$ dari $17,5 \%$ saat masuk menjadi $24,3 \%$ saat pulang. Peningkatan pasien underweight dan wasting tersebut diatas semuanya berasal dari status gizi normal pada saat masuk rumah sakit. Kekurangan penelitian tidak mencari faktor risiko lain seperti karakteristik orangtua anak, keadaan sosial ekonomi orangtua dan asupan nutrisi selama anak menjalani rawat inap yang kemungkinan juga mempengaruhi insidens MRI.

\section{Kesimpulan}

Berdasarkan hasil penelitian, disimpulkan bahwa insidens MRI di RSUP Sanglah Denpasar 30,1\%. Satu-satunya faktor yang berhubungan dengan insidens MRI adalah lama rawat; semakin lama dirawat semakin tinggi insidens MRI. Sebagai konsekuensinya prevalensi malnutrisi (underweight dan wasting) saat keluar dari rumah sakit juga meningkat. Langkah strategis untuk mengatasi MRI adalah membudayakan penilaian status nutrisi pada setiap pasien rawat inap terutama anak balita, mengoptimalkan kerja sama 
dalam tim asuhan gizi rumah sakit, dan menciptakan sistem yang efisien untuk deteksi dini anak balita yang berisiko mengalami MRI.

\section{Daftar Pustaka}

1. Grigsby DG, Harohalli RS. Malnutrition. Didapat dari: http://www.emedicine.com/PED/topic1360.htm. Diakses tanggal 30 Juni 2006.

2. Scheinfeld NS, Mokashi A, Lin A, Santoro D. Protein-Energy Malnutrition. Didapat dari: http://www. emedicine.com/ derm/topic797.htm. Diakses tanggal 11 Agustus 2006.

3. World Health Organization. Nutrition for health and development: a global agenda for combating malnutrition. Department of Nutrition for Health and Development. Geneva, 2000.

4. De Onis M, Monteiro C, Akre J, Clugston G. The worldwide magnitude of protein-energy malnutrition: an overview from the WHO Global Database on Child Growth. Bull WHO. 1993;71:703-12.

5. Departemen Kesehatan RI. Pedoman Tata laksana kurang energi protein pada anak di rumah sakit Kabupaten/Kodya. Jakarta, 2000.
6. Sudaryat, Soetjiningsih. Penyunting. Pedoman diagnosis dan terapi ilmu kesehatan anak RSUP Sanglah. Denpasar: Lab/SMF Ilmu Kesehatan Anak FK Unud/ RSUP Sanglah, 2000. h. 79-84

7. Jalil F. Nutrition in Acute Diarrhea. Nestle Nutr Workshop. Switzerland: Nestec Ltd, 1996. h. 12-14.

8. Geila AR, Rocha EJM, Martins CV. The effects of hospitalization on the nutritional status of children. J Pediatr (Rio J) 2006;82:70-4.

9. World Health Organization. WHO Anthro 2005 software for assessing growth and development of the world's children. Department of Nutrition for Health and Development. Geneva, Switzerland, 2006.

10. De Onis M, Onyango AW, Borghi E, Garza C, Yang H. Comparison of the World Health Organization (WHO) Child Growth Standards and the National Center for Health Statistics/WHO international growth reference: implications for child health programs. Public Health Nutrition 2006;9:942-7.

11. Kac G, Camacho-Dias P, Silva-Coutinho D, SilveiraLopes R, Vilas-Boas V, Pinheiro ABV. Length of stay is associated with incidence of in-hospital malnutrition in a group of low-income Brazillian children. Salud Publica Mex. 2000;42:407-12. 